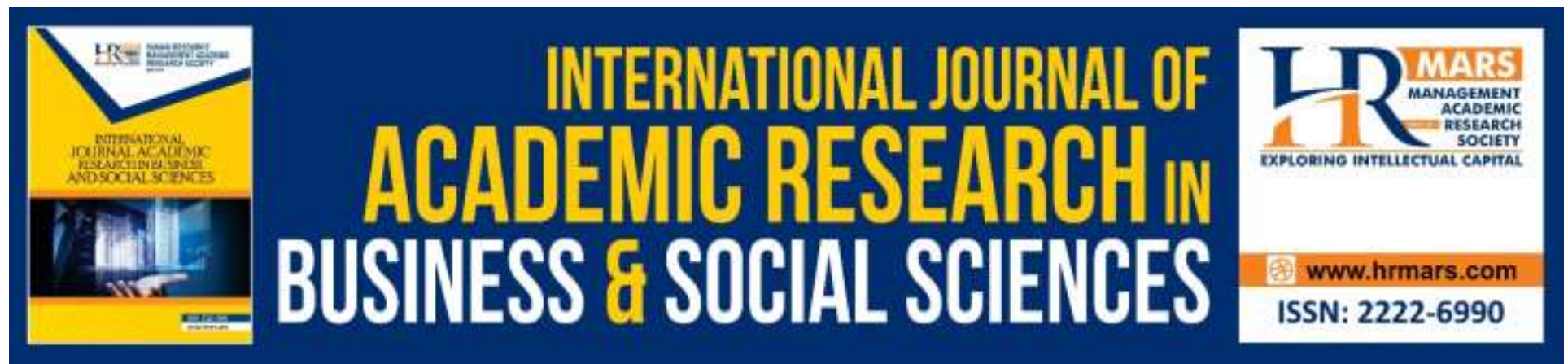

\title{
The Image of the Department of Islamic Development Malaysia
}

\author{
Fadzila Azni Ahmad, Noor Aini Mohd Salleh
}

To Link this Article: http://dx.doi.org/10.6007/IJARBSS/v9-i11/6589

DOI: 10.6007/IJARBSS/v9-i11/6589

Received: 12 October 2019, Revised: 30 October 2019, Accepted: 08 November 2019

Published Online: 29 November 2019

In-Text Citation: (Ling et al, 2019)

To Cite this Article: Ahmad, F. A., Salleh, N. A. M. (2019). The Image of the Department of Islamic Development Malaysia. International Journal of Academic Research in Business and Social Sciences, 9(11), 673-684.

Copyright: (c) 2019 The Author(s)

Published by Human Resource Management Academic Research Society (www.hrmars.com)

This article is published under the Creative Commons Attribution (CC BY 4.0) license. Anyone may reproduce, distribute, translate and create derivative works of this article (for both commercial and non-commercial purposes), subject to full attribution to the original publication and authors. The full terms of this license may be seen

at: http://creativecommons.org/licences/by/4.0/legalcode

Vol. 9, No. 11, 2019, Pg. 673- 684

http://hrmars.com/index.php/pages/detail/IJARBSS

JOURNAL HOMEPAGE

Full Terms \& Conditions of access and use can be found at http://hrmars.com/index.php/pages/detail/publication-ethics 


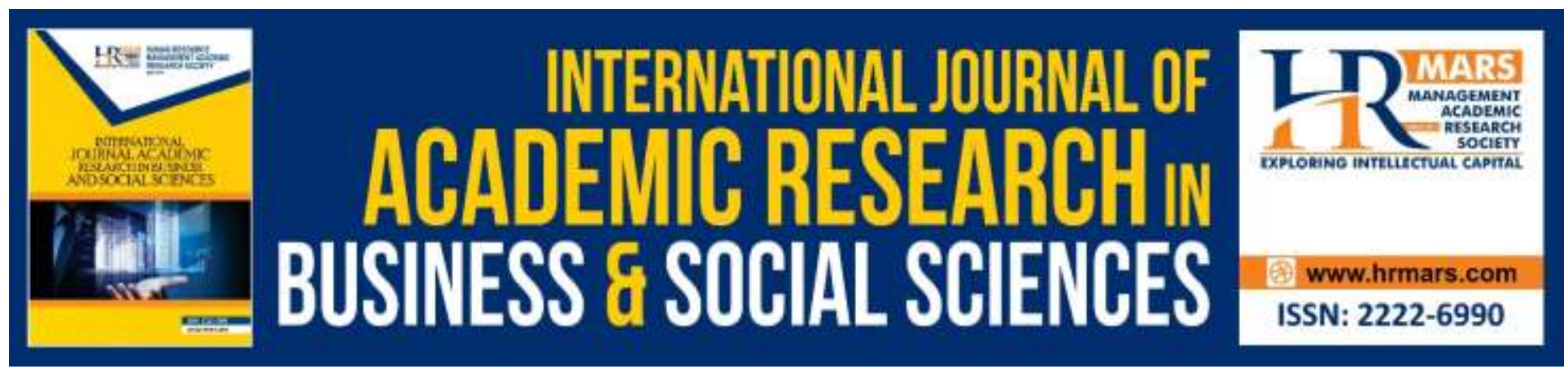

\title{
The Image of the Department of Islamic Development Malaysia
}

\author{
Fadzila Azni Ahmad \\ Centre for Islamic Development Management Studies (ISDEV) Universiti Sains Malaysia, Penang, \\ Malaysia \\ Noor Aini Mohd Salleh \\ Centre for Islamic Development Management Studies (ISDEV) Universiti Sains Malaysia, Penang, \\ Malaysia
}

\begin{abstract}
This article intended to examine the image of the principal Islamic institution in this country held by the general public, which is the Department of Islamic Development, Malaysia or JAKIM. JAKIM is the institution responsible for managing the affairs of Muslims in Malaysia, including the assurance of halal foodstuff for Muslims in Malaysia in the form of issuing halal certifications. Halal certification, which is supervised and issued by JAKIM, has put Malaysia on the world map, especially in reference to the halal industry. Hence, what is the image of JAKIM as an Islamic institution responsible for managing Islamic affairs and Muslims in this country? The online survey method was applied and involved 473 samples. The findings contradicted mainstream thinking, which indicated that Islamic institutions are not very relevant in the 'Malaysia Baharu' context and the contemporary society.
\end{abstract}

Keywords: JAKIM, Image, Islamic Institutions, Reputation Management, Halal, Certification

\section{Introduction}

The word 'image' can be understood to be the 'perception', 'presumption', 'portrayal' or 'views' about something that exist in a person's mind. Image plays a significant role in a person, institution or even a country. This study had examined the image of the principal Islamic institution in Malaysia, namely the Department of Islamic Development, Malaysia or JAKIM, by applying the online survey method involving the general public in Malaysia. This study intended to determine the actual image of JAKIM in the eyes of the general public. There are three parts in this study. First is the background and related issues and the second is about the image of 
JAKIM in the eyes of the general public. The last part touches on conclusions derived from discussions in part one and two.

\section{Background and Issues}

Generally, image is an element in strategic management as well as a component in the mission statement of an institution (Mohamed, 2007; Jamal, 2018). The strategic management concept is a tool for helping an institution to better manage its image and to have a strategic plan. Among the elements of strategic management is corporate culture, image, profile, human resources management and rewards for employees (Rahman, 1994; Ilemona, Sunday, 2018).

Image management, being one of the most important elements, acts as a tool required to achieve an effective management system that can produce desired results, which can be in the form of language, behaviour, symbols, tradition, culture and perception as well as not being limited to products, services or human resources (Mat, 2007). Hence, image management helps an individual or organization to enhance skills such as humanistic, technical, time management, decision-making and overcoming psychological problems. Image management is also closely related to acceptance by the general public and the functional value of an organization. Therefore, image management of an Islamic development institution, such as JAKIM, Islamic banks, Islamic educational institutions, not only bears importance on the technical aspect of management but also considers religious values when implementing a policy or observing the hablumminallah and hablumminannas relationships. Portraying a positive image contributes towards building an institution's good image. Hence, there are various ways for an institution to enhance its image, for example, by advertising, marketing or rebranding.

A good image can help the institution in portraying its success, quality and productivity, which has been produced for mutual benefit, to the general public. Thus, the image is a component that should not be neglected but rather, should be safeguarded and given serious attention. According to Marken (1990) as well as the Opinion Research Corporation (ORC) report, image is an important element in marketing and production activities. Studies have shown that $97 \%$ of feedback from senior and middle managers indicate that image is a significant measure in determining an institution's success or failure (Mohamad et al., 2003; Sinha, 2019).

The image of an institution does not appear overnight but is born from the identity owned and portrayed by the institution that practices strategic management via the implementation of effective services and communication (Mohamad et al., 2003). It is clear that an institution's success depends on the skills in managing the image by employees of the institution themselves. Conversely, for an Islamic institution, what is more important is to manage the image by assimilating principles stipulated in the basic management of an Islamic development institution. Hence, when managing the image of an Islamic development institution it is important to understand and manage the institution according to the basic principles of Islamic-based development. This initiative will not only garner the society's support, but it will also be very 
highly valued, from the Islamic aspect. In accordance with the objective of this study, the next discussion in the background and issues section deals with JAKIM's background, which is the institution of focus in this study.

The origins of forming JAKIM started on 17 October 1968, when the Meeting of the Council of Rulers formed the National Council of Islamic Affairs (MKI). The government then formed the Religious Section in the Prime Minister's Department (JPM), as the secretariat for the MKI. This Religious Section then became the Islamic Affairs Section (BAHEIS), which on 1 January 1997 became the Department of Islamic Development Malaysia (JAKIM) (Manan et al., 1999).

JAKIM is the main religious agency at the federal level and has branches in all the states, including Sabah and Sarawak. This institution is famous for being the main institution for the administration of Islam in Malaysia. It also formulates policies as well as coordinates development and progress of Islamic affairs in Malaysia (JAKIM, 2019). According to Wan Aziz (2011), JAKIM formulates and maintains the uniformity of syarak or civil law, coordinates Islamic administration as well as develops and coordinates Islamic education. In addition, JAKIM implements tasks for $\mathrm{MKI}$, such as discussions, arbitrations or evaluations as well as managing and providing advice related to Islam. Usually, JAKIM is assisted by MAIN and/or JAIN at the state level.

Generally, JAKIM is the body that coordinates halal certification activities and prepares comprehensive guidelines for halal products (Hasan, 2007), including procedures related to examining, validating and the application, approval, conditions, inspection and enforcement of halal certificates (Mustapha, 2013). Halal certification by JAKIM in Malaysia has positively expanded and has been received well at the international level. JAKIM has been given ownership of the Malaysian halal logo. Moreover, JAKIM's halal certificate has safety features designed by SIRIM (Abidin, 2010:13). Until today, JAKIM's halal logo has been receiving high recognition from Islamic countries.

Besides being the sole entity that issues halal certification, JAKIM has been given the mandate by the government to become the secretariat for formulating and coordinating policies related to Islamic affairs at the national level. Some of the committees and events organised by JAKIM are the Committee for the Development of Islamic Affairs, National Fatwa Committee, All-Malaysia Conference of Chairmen for Islamic Affairs, All-Malaysia Conference of Heads of Departments or Islamic Religious Councils, Consultative Body for Islam and many more (Manan et al, 1999). In summary, JAKIM is an important body for managing the development of Islamic affairs and substantiating society's spiritual strength (JAKIM, 2009). In taking on this function, JAKIM has acted to emplace religious officers in hospitals in order to offer religious advisory services to patients. JAKIM had formed the Committee for Coordinating Mualaf Registrations in order to address the welfare of the Mualaf with the cooperation of JAIN and MAIN (Mustapha, 2013). 
Besides that, JAKIM has made efforts to monitor the Syiah movement with the cooperation of JAIN.

However, mainstream media reports and previous studies have raised various perceptions about JAKIM, which has had various effects on JAKIM's image. For example, this important nationallevel administrative institution has been frequently targeted or turned into a 'black sheep' each time an issue related to Islam or Muslims in Malaysia arises. JAKIM has received criticism regarding transparency, truthfulness and commitment aspects related to issues such as halal and haram foodstuff and cosmetics consumed by the Muslim community in this country (Malik, 2014). There are allegations of JAKIM's failure in handling the issue of a website that had insulted Islam and sources that can destabilise the community's faith (akidah) (Faizal, 2010).

Besides that, there are allegations that JAKIM staff are in cohorts with a syndicate that offers false marriage certificates (Ahmad, 2011), instigating sentiments of hate among Muslims towards Christians regarding the issue of using Kalimah Allah during Friday sermons (Samad \& Eu, 2013). These issues not only jeopardise the trust that the community has in JAKIM, but it also affects JAKIM as an institution.

Another issue is that related to Islam Hadhari, which was previously introduced at the federal level (Othman \& Fadlillah, 2012). The study mentioned that JAKIM was accused of not carrying out its responsibility in introducing the Islam Hadhari approach to the community as it had raised numerous questions and reactions. It is said that this was the reason why the community lacked an understanding of the Islam Hadhari concept that was propagated by the country's leadership at that time as an effort to return the splendour of the Islamic civilization. Conversely, Yusuf and Ismail (2006) contradicted these allegations by stating that JAKIM had actually been actively enlightening the community about Islam Hadhari. In fact, various perceptions that exist actually originated based on knowledge or understanding held by the general public itself.

Therefore, the question arises as to why there are various perceptions. Is the general public knowledgeable about JAKIM? Is the general public aware of JAKIM's roles? Are the perceptions or image about JAKIM accurate? Has JAKIM failed to play its role as stipulated? The discussions in this study aimed to determine the level of understanding and the various perceptions held by the general public regarding JAKIM. This study had applied the online survey method and used the 'unrestricted self-selected survey' sampling method. The characteristics of this sampling method are the absence of a condition as to who actually should take part in this survey and the respondent who receives the survey question reserves the right to take part or otherwise (Fricker, 2002). It is hoped that the results of this study will reveal the actual image of JAKIM held by the general public in Malaysia. 
INTERNATIONAL JOURNAL OF ACADEMIC RESEARCH IN BUSINESS AND SOCIAL SCIENCES

Vol. 9, No. 11, November, 2019, E-ISSN: 2222-6990 ㄷ 2019 HRMARS

\section{Findings and Discussions}

As shown in Table 1 below, there were 473 respondents involved in this study. Information about the number of respondents according to demographics such as gender, ethnicity, religion, age range, education and employment are shown in Table 1 below.

Table 1: Respondent's Demographic Parameters

\begin{tabular}{|c|c|c|}
\hline & Frequency & Percentage \\
\hline \multicolumn{3}{|l|}{ Gender } \\
\hline Male & 173 & $36.6 \%$ \\
\hline female & 300 & $63.4 \%$ \\
\hline Total: & 473 & $100.0 \%$ \\
\hline \multicolumn{3}{|l|}{ Ethnicity } \\
\hline Malay & 461 & $97.5 \%$ \\
\hline Chinese & 2 & $0.4 \%$ \\
\hline Indian & 2 & $0.4 \%$ \\
\hline Bumiputra from Sabah \& Sarawak & 8 & $1.7 \%$ \\
\hline Total: & 473 & $100.0 \%$ \\
\hline \multicolumn{3}{|l|}{ Religion } \\
\hline Islam & 471 & $99.6 \%$ \\
\hline Non-Islam & 2 & $0.4 \%$ \\
\hline Total: & 473 & $100.0 \%$ \\
\hline \multicolumn{3}{|l|}{ Age } \\
\hline Less than 20 years & 16 & $3.4 \%$ \\
\hline $21-30$ years & 139 & $29.4 \%$ \\
\hline $31-40$ years & 151 & $31.9 \%$ \\
\hline $41-50$ years & 94 & $19.9 \%$ \\
\hline $51-60$ years & 59 & $12.5 \%$ \\
\hline More than 60 years & 14 & $3.0 \%$ \\
\hline Total: & 473 & $100.0 \%$ \\
\hline
\end{tabular}


Table 1: Respondent's Demographic Parameters (cntd)

\begin{tabular}{|c|c|c|}
\hline \multicolumn{3}{|l|}{ Level of Education } \\
\hline Primary level & 2 & $0.4 \%$ \\
\hline Secondary level & 16 & $3.4 \%$ \\
\hline $\begin{array}{l}\text { Certificate/Diploma/Matriculation/ } \\
\text { STPM }\end{array}$ & 118 & $24.9 \%$ \\
\hline Degree & 199 & $42.1 \%$ \\
\hline Master & 104 & $22.0 \%$ \\
\hline Doctor of Philosophy & 34 & $7.2 \%$ \\
\hline Total: & 473 & $100.0 \%$ \\
\hline \multicolumn{3}{|l|}{ Education background } \\
\hline Academic & 321 & $67.9 \%$ \\
\hline Religion & 116 & $24.5 \%$ \\
\hline Skills/Vocational & 36 & $7.6 \%$ \\
\hline Total: & 473 & $100.0 \%$ \\
\hline \multicolumn{3}{|l|}{ Information about the employment sector } \\
\hline Government employee & 207 & $43.8 \%$ \\
\hline Private sector employee & 132 & $27.9 \%$ \\
\hline Self-employed & 53 & $11.2 \%$ \\
\hline Presently unemployed & 81 & $17.1 \%$ \\
\hline Total: & 473 & $100.0 \%$ \\
\hline \multicolumn{3}{|l|}{ Field of Work/ Learning } \\
\hline Education & 175 & $37.0 \%$ \\
\hline Administration & 89 & $18.8 \%$ \\
\hline Medical/Dentistry/Veterinary & 24 & $5.1 \%$ \\
\hline Law & 7 & $1.5 \%$ \\
\hline Finance/Economy & 40 & $8.5 \%$ \\
\hline Business & 43 & $9.1 \%$ \\
\hline Hotel/Tourism/Hospitality & 25 & $5.3 \%$ \\
\hline Engineering/Technical & 37 & $7.8 \%$ \\
\hline Computerisation & 5 & $1.1 \%$ \\
\hline Environment & 10 & $2.1 \%$ \\
\hline Fashion/Fine arts/Media/Filming/Journalism & 5 & $1.1 \%$ \\
\hline Architecture/Building Planning and Development & 9 & $1.9 \%$ \\
\hline Agriculture & 4 & $0.8 \%$ \\
\hline Total: & 473 & $100.0 \%$ \\
\hline
\end{tabular}

Source: Online survey (2018) 
Knowledge about JAKIM varied among the 473 respondents as shown in Table 2. However, almost all respondents were aware of JAKIM's existence.

Table 2: Respondents' Knowledge about JAKIM

\begin{tabular}{|c|c|c|c|}
\hline & Yes & No & Total \\
\hline Knowledge about the existence of JAKIM & $\begin{array}{c}472 \\
(99.8 \%)\end{array}$ & $\begin{array}{c}1 \\
(0.2 \%)\end{array}$ & $\begin{array}{c}473 \\
(100 \%)\end{array}$ \\
\hline Knowledge about the functions of JAKIM & $\begin{array}{c}427 \\
(90.3 \%)\end{array}$ & $\begin{array}{c}46 \\
(9.7 \%)\end{array}$ & $\begin{array}{c}473 \\
(100 \%)\end{array}$ \\
\hline Knowledge about JAKIM's logo & $\begin{array}{c}382 \\
(80.8 \%) \\
\end{array}$ & $\begin{array}{c}91 \\
(19.2 \%) \\
\end{array}$ & $\begin{array}{c}473 \\
(100 \%) \\
\end{array}$ \\
\hline $\begin{array}{l}\text { Knowledge about the location of JAKIM's centre of } \\
\text { administration }\end{array}$ & $\begin{array}{c}318 \\
(67.2 \%) \\
\end{array}$ & $\begin{array}{c}155 \\
(32.8 \%) \\
\end{array}$ & $\begin{array}{c}473 \\
(100 \%) \\
\end{array}$ \\
\hline Knowledge about who is the Director General of JAKIM & $\begin{array}{c}158 \\
(33.4 \%)\end{array}$ & $\begin{array}{c}315 \\
(66.6 \%)\end{array}$ & $\begin{array}{c}473 \\
(100 \%)\end{array}$ \\
\hline Knowledge about when JAKIM was established & $\begin{array}{c}113 \\
(23.9 \%)\end{array}$ & $\begin{array}{c}360 \\
(76.1 \%)\end{array}$ & $\begin{array}{c}473 \\
(100 \%)\end{array}$ \\
\hline Knowledge about which Ministry is responsible for JAKIM & $\begin{array}{c}337 \\
(71.2 \%)\end{array}$ & $\begin{array}{c}136 \\
(28.8 \%)\end{array}$ & $\begin{array}{c}473 \\
(100 \%)\end{array}$ \\
\hline Knowledge about which Minister is responsible for JAKIM & $\begin{array}{c}330 \\
(69.8 \%)\end{array}$ & $\begin{array}{c}143 \\
(30.2 \%)\end{array}$ & $\begin{array}{c}473 \\
(100 \%)\end{array}$ \\
\hline
\end{tabular}

Source: Online survey (2018)

Generally, the respondent's knowledge about JAKIM was 'very good' except knowledge related to its leadership or the Director General of JAKIM and the year JAKIM was established, whereby on $35 \%$ or less of the respondents were knowledgeable. 
INTERNATIONAL JOURNAL OF ACADEMIC RESEARCH IN BUSINESS AND SOCIAL SCIENCES Vol. 9, No. 11, November, 2019, E-ISSN: 2222-6990 @ 2019 HRMARS

The respondent obtained knowledge from various sources as shown in Diagram 1 below.

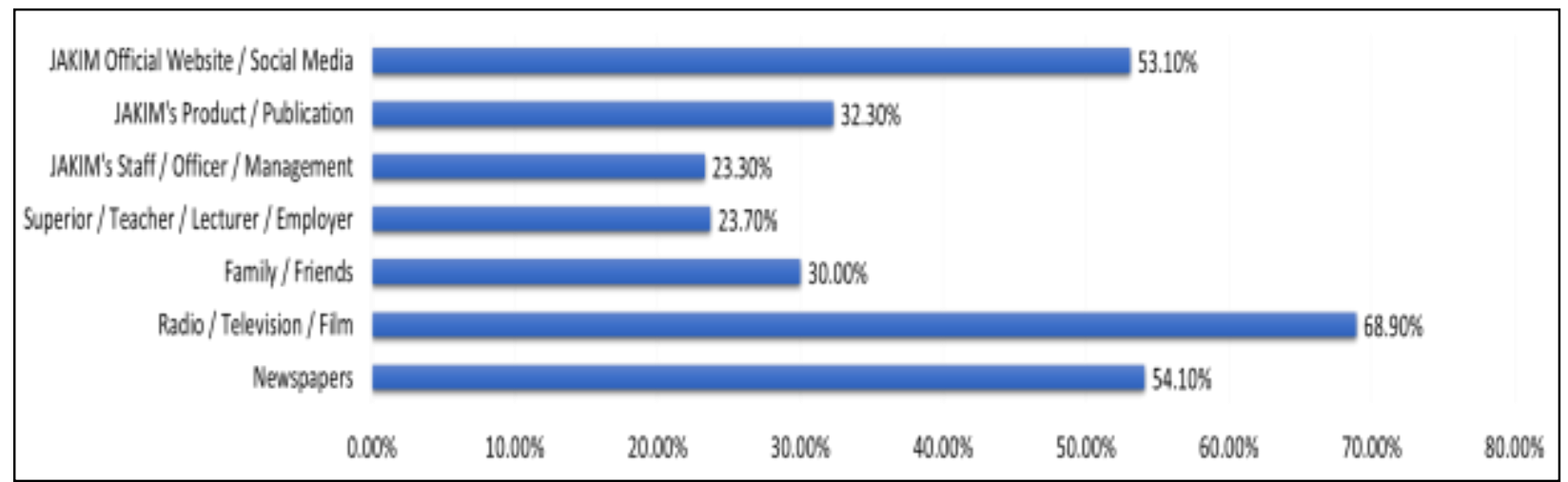

Diagram 1: Respondents' Source of Knowledge about JAKIM

Source: Online survey (2018)

Generally, based on Diagram 1, the medium that contributed the most amount of knowledge about JAKIM to respondents is the mass media (newspapers, television, film, the Internet and either the official website or the social media belonging to JAKIM)

Next, JAKIM's image among respondents involved in the survey are as shown in Diagram 2. Generally, respondents had a positive perception about all the aspects and functions of JAKIM. In relation to all the aspects, a positive perception, either at the 'very good', 'good' or 'moderate' levels, was posted by more than $80 \%$ of respondents. This indicates that respondents had a positive image about JAKIM. However, when respondents were asked about specific elements in JAKIM, such as the staff, leadership and products, the percentage of respondents who had a positive view had decreased but was still 'good', generally. This is shown next in Diagram 3.

Diagram 2 Note: $\underline{a}$ - As a monitoring body to hinder mungkar activities from occurring; $\mathrm{b}$ - As a body that implements halal certification in Malaysia; c - As the highest platform for safeguarding the religious affairs of Malaysian Muslims; $d$ - As an advisor and coordinator on matters related to Islamic education at the national level; e - As an organizational management model for Islamic institutions, specifically for the Islamic Religious department of various states; $f$ - In implementing research related to issues concerning Muslim, which is eventually decided by the Fatwa Committee Muzakarah; g - Benefits various mediums of social media (websites, Internet, radio and television) by playing its role; $h$ - As a body that preaches to the whole of society in Malaysia; $\mathrm{i}$ - As an adversary body to the government on religious issues; $\mathrm{j}$ - Generally 
INTERNATIONAL JOURNAL OF ACADEMIC RESEARCH IN BUSINESS AND SOCIAL SCIENCES

Vol. 9, No. 11, November, 2019, E-ISSN: 2222-6990 @ 2019 HRMARS

\section{Diagram 3: JAKIM's image based on certain aspects according to respondents}

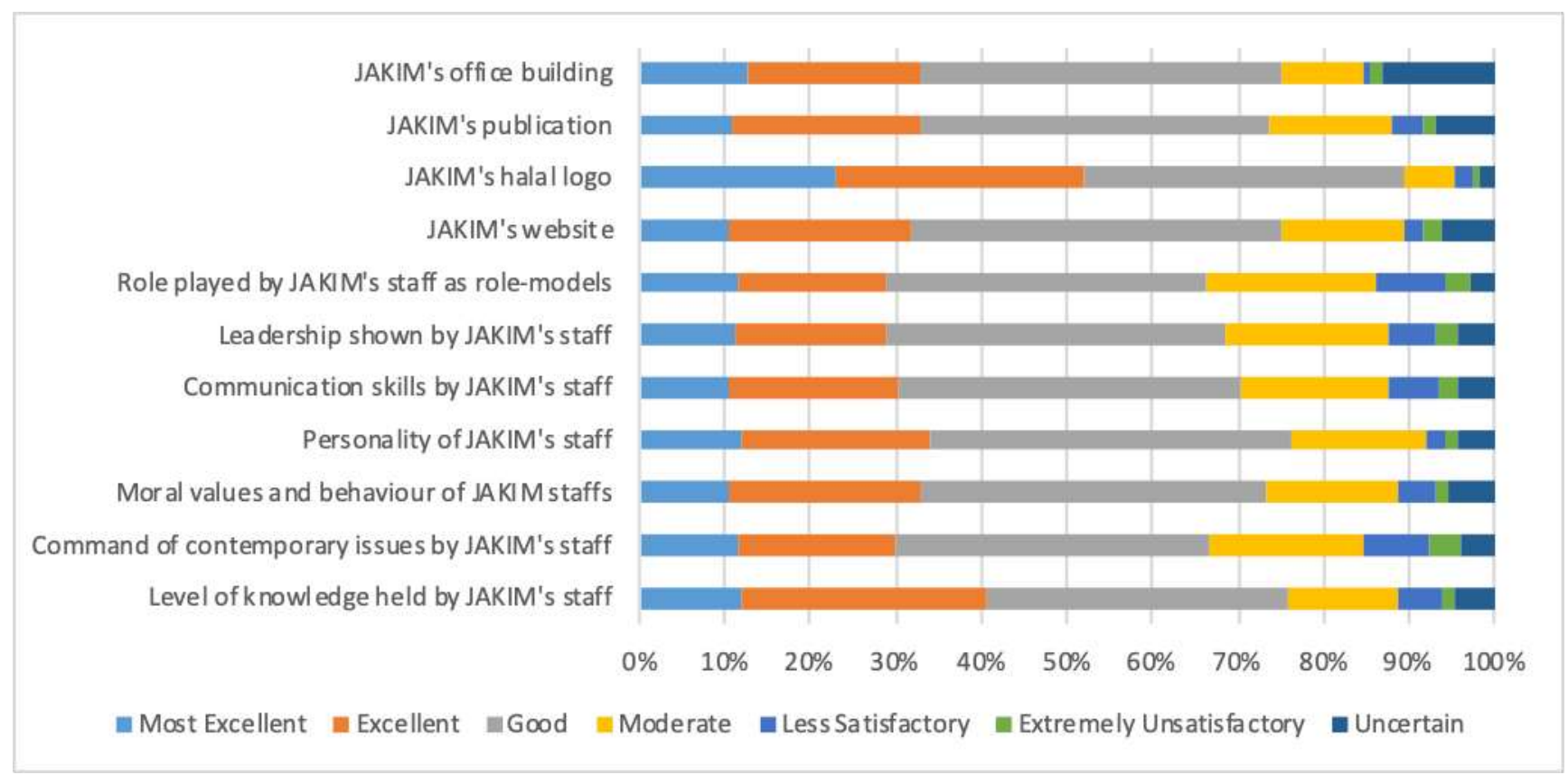

\section{Summary and Conclusion}

Based on the survey, majority of the respondents were satisfied with JAKIM. These respondents had vast amounts of positive knowledge about JAKIM, which means that their perceptions are based on knowledge and information. Implications from this study can prove that JAKIM is not an institution that has a negative or bad image held by Muslims in this country.

\section{Acknowledgement}

Sincere appreciation to Universiti Sains Malaysia for funding part of this study under the ShortTerm Grant entitled The Position of Hisbah and Negative Perceptions About Islamic Development in Malaysia (304 / CISDEV / 6315131).

\section{Corresponding Author}

Fadzila Azni Ahmad

Centre for Islamic Development Management Studies (ISDEV)

Universiti Sains Malaysia, Penang, Malaysia

Email: sukainah@usm.my 
INTERNATIONAL JOURNAL OF ACADEMIC RESEARCH IN BUSINESS AND SOCIAL SCIENCES

Vol. 9, No. 11, November, 2019, E-ISSN: 2222-6990 @ 2019 HRMARS

\section{References}

Abidin, N. Z. (2010). Persepsi pelajar terhadap Malaysia sebagai Hub Makanan Halal: Kajian terhadap Pelajar Islam 4 SPH Fakulti Pendidikan. Disertasi tidak diterbitkan, Universiti Teknologi Malaysia, Skudai

Ahmad, N. (2011). Tan Sri, Artis antara 500 Guna Sindiket Nikah Palsu. Berita Harian, Retrieved from: https://www.bharian.com.my/bharian/articles/TanSri_artisantara500

Aziz, W. M. S. A. (2011). Pelan penyelarasan perundangan Islam di Malaysia. Kuala Lumpur: Jabatan Kemajuan Islam Malaysia.

Faizal, M. (2010). Hina Islam Jingga Pohon Menghadap Agong. Harakah Daily. Retrieved from http://bm.harakahdaily.net/index.php/berita-utama/5341-hina-islam-jingga -13-mohonmengadap-agong.

Fricker, R. D. J., \& Schonlau, M. (2002), “Advantages and disadvantages of internet research surveys: evidence from the literature", Field Methods, 14 (4), 347-67.

gunasindiketnikahpalsu/Article

Hasan, Z. (2006). The role and respinsibilities of the Shariah Committee of The Islamic Financial Institution in Malaysia. Jurnal Syariah, 14 (1). pp. 77-91.

Ilemona, S. A., Sunday, N. (2018). Budget Implementation and Economic Growth in Nigeria: An Exploratory Review (2014-2018), International Journal of Academic Research in Accounting, Finance and Management Sciences 8 (4): 171-176. http://dx.doi.org/10.6007/IJAR

JAKIM (2019). Perutusan Ketua Pengarah, JAKIM Official Website. Retrieved from: http://www.islam.gov.my/mengenai-jakim/perutusan-ketua-pengarah

Jamal, S. H. (2018). The Catalyst Factors of Counselor's Competencies in Handling Gay and Lesbian Clients. International Journal of Academic Research in Progressive Education and Development, 7(4), 231-245.

Malik, M. (2014). JAKIM wajar diyakini. Astro Awani. Retrieved from: http://www.astroawani.com/perspektif/jakim-wajar-diyakini-37096

Manan, M. Z. A., Kasan, H., \& Bahall, M. Z. (1999). Pembangunan Islam di Malaysia. Kuala Lumpur: Jabatan Kemajuan Islam Malaysia (JAKIM).

Marken, G. A. (1990). Corporate image - We all have one, but few work to protect and project it. Public Relations Quarterly. Vol. 35 (1). 21-24.

Mat, C. (2007). Pengurusan imej. Kuala Lumpur: Utusan Publications \& Distributors.

Mohamad, B., Mohamed, R., \& Bakar, H. A. (2003, Jun 27-28). Identiti, Imej dan Reputasi Persatuan Nelayan Kawasan Kuala Perlis Selatan. Seminar Kebangsaan Syariah dan Koperasi 2003. Organised by Kolej Universiti Islam Malaysia di Hotel Equatorial, Bangi.

Mohamed, Z. A. (2007). Pengurusan strategi. Kuala lumpur: Utusan Publications \& Distributors.

Mustapha, O. (2013). Kenyataan Media Ketua pengarah JAKIM mengenai pelaksanaan penguatkuasaan halal. Retrieved from http://www. islam.gov.my/sites/default/ files/bahagian/bpict/doc/kenyataan_media_kp17.pdf

Othman, M. R., \& Fadlilah, A. (2012). Perspektif Badan Bukan Kerajaan (NGO) Islam terhadap Dasar Penerapan Nilai-nilai Islam dan Pendekatan Islam Hadhari. Jurnal Hadhari 4 (1) 4974. 
Pelan Strategik JAKIM 2009-2014 (2009). Memacu transformasi pengurusan hal ehwal Islam. Putrajaya: Jabatan Kemajuan Islam Malaysia

Rahman, A. A. A. (1994). Falsafah dan Teknik Pengurusan. Kuala Lumpur: Berita Publishing.

Samad, K. A., \& Eu, H. S. (2013). Pertikai isi khutbah derhaka kepada institusi diraja - Mufti Pahang, Astro Awani. Retrieved from: http://www.astroawani.com/beritamalaysia/pertikai-isi-khutbah-derhaka-kepada-institusi-diraja-mufti-pahang-22393

Sinha, R. B. N. (2019). Development of Social Capital Measures in Indian Context. Multilingual Academic Journal of Education and Social Sciences, 7(1), 22-28. 